\title{
PENGARUH SEDENTARY BEHAVIOR TERHADAP OBESITAS PADA ANAK
} SEKOLAH

\author{
Megawati $^{1}$, Rizka Norazizah ${ }^{2}$, Norlaila Sofia ${ }^{3}$ \\ Akademi Kebidanan Panca Bhakti Pontianak \\ Email korespondensi: irawanmegawati@gmail.com,rizkanorazizahandriyadi@gmail.com
}

\begin{abstract}
Abstrak
Obesitas merupakan suatu kelainan atau penyakit yang ditandai dengan penimbunan lemak tubuh secara berlebih. Obesitas memiliki hubungan yang bermakna terhadap usia harapan hidup seseorang. Individu yang sudah mengalami obesitas sejak masa kanak-kanaknya mempunyai risiko yang lebih besar terkena penyakitpenyakit metabolik di masa yang akan mendatang. Implikasi dan konsekuensi yang ditimbulkan obesitas pada masa anak-anak saat ini dianggap masa krusial yang menentukan derajat kesehatan di tahap usia selanjutnya. Obesitas anak diprediksi berhubungan dengan kebiasaan yang tidak aktif yang mengarah pada perilaku kurang gerak (sedentary behavior). Aktivitas fisik memberi peran penting dalam pengeluaran energi karena $20-50 \%$ energi dikeluarkan dengan aktivitas fisik. Kurang aktivitas fisik menyebabkan kelebihan energi akan disimpan dalam bentuk jaringan lemak. Penelitian ini dilakukan untuk mengetahui pengaruh sedentary behavior terhadap obesitas pada anak sekolah. Penelitian ini menggunakan metode tinjauan literatur (literature review) yang mencoba menggali bagaimana pengaruh sedentary behavior terhadap obesitas pada anak sekolah. Sumber untuk melakukan tinjauan literatur ini meliputi studi pencarian sistematis database terkomputerisasi (Pubmed, Google Scholar) dalam bentuk jurnal penelitian berjumlah 21 jurnal. Hasil penelitian menunjukkan terdapat pengaruh sedentary behavior terhadap obesitas bila dilihat dari nilai $p$ $=0,0005$ dengan metode yang digunakan. Pearson koefisien korelasi. Chi-square digunakan untuk melihat hubungan antara perbedaan lama waktu screen based activity (SBA) anak dalam kelompok gemuk dan tidak gemuk. Kesimpulan dalam penanganan obesitas pada anak sekolah dengan melakukan intervensi peningkatan aktifitas fisik dan menjalani perilaku makan yang sehat dapat mengurangi prevalensi obesitas pada anak sekolah.
\end{abstract}

Kata kunci: Perilaku kurang gerak, Obesitas, Anak sekolah

\begin{abstract}
Obesity is a disorder or disease that correlates with excess body fat accumulation. Obesity has a relationship with the life expectancy of a person. A person who has been obese since childhood has a greater risk of developing metabolic diseases in the future. The implications and impacts caused by childhood at this time are crucial in determining the degree of health at a later stage of age. It is predicted that childhood obesity is associated with sedentary habits which refers to sedentary behavior. Physical activity plays an important role in energy expenditure because $20-50 \%$ of the energy is expended by physical activity. Physical activity with excess energy is stored in the form of fat tissue. This study was conducted to see the effect of sedentary behavior on obesity in school children. This study uses a literature review method which tries to find out how sedentary behavior affects obesity in school children. Sources for conducting this literature review include a systematic study of computerized databases (Pubmed, Google Scholar) in the form of 21 research journals. The results showed that there was an effect of sedentary behavior on obesity when viewed from the value of $p=0.0005$ with the method used. Pearson coefficient. Chi-square was used to see the relationship between differences in the length of time on screen based activity (SBA) of children in the obese and not obese groups. Conclusion in handling obesity in school children by intervening to increase physical activity and healthy eating behavior can reduce the prevalence of obesity in school children.
\end{abstract}

Keywords: Sedentary behavior, Obesity, School children

\footnotetext{
${ }^{1}$ Dosen Politeknik Kementerian Kesehatan Banjarmasin

${ }^{2}$ Dosen Universitas Sari Mulia Banjarmasin

${ }^{3}$ Dosen Politeknik Kementerian Kesehatan Banjarmasin
} 


\section{Pendahuluan}

Masalah gizi anak di Indonesia saat ini memasuki masalah gizi ganda. Artinya, masalah gizi kurang masih belum bisa teratasi sepenuhnya sementara sudah muncul masalah baru yakni masalah gizi lebih. Ada beberapa masalah yang berkaitan dengan konsumsi zat gizi, diantaranya adalah gizi lebih (obesitas), gizi kurang (malnutrisi), penyakit metabolik dan keracunan makanan (Sartika., 2011).

Obesitas di Indonesia saat ini belum menjadi sorotan karena masih disibukkan dengan masalah anak yang kekurangan gizi. Namun, kini sudah saatnya Indonesia mulai melirik pada masalah obesitas pada anak karena jika dibiarkan, akan mengganggu sumber daya manusia (SDM) di kemudian hari. Obesitas merupakan suatu kelainan atau penyakit yang ditandai dengan penimbunan lemak tubuh secara berlebih. Obesitas pada anak adalah kondisi medis pada anak yang memiliki Indeks Massa tubuh (IMT) +2 standar deviasi. IMT dihitung dengan cara mengalikan berat badan anak kemudian dibagi dengan kuadrat dari besar tinggi akan yang kemudian hasilnya dibandingkan dengan kurva standar deviasi (Riskesdas., 2013)

Obesitas memiliki hubungan yang bermakna terhadap usia harapan hidup seseorang. Individu yang sudah mengalami obesitas sejak masa kanak-kanaknya mempunyai risiko yang lebih besar terkena penyakit-penyakit metabolik di masa yang akan datang. Implikasi dan konsekuensi yang ditimbulkan obesitas pada masa anak-anak saat ini dianggap masa krusial yang akan menentukan derajat kesehatan di tahap usia selanjutnya.

Tahun 2013 prevalensi obesitas di Indonesia pada anak usia 5-12 tahun sebesar $18,8 \%$, usia $13-15$ tahun sebesar $10,8 \%$ dan usia 16-18 tahun sebesar 7,3\%. Penelitian di Arab Saudi terhadap 197 anak sekolah lakilaki usia 9-14 tahun, hasilnya menunjukkan $24,9 \%$ obesitas dan $15,2 \%$ kegemukan. Perilaku mengonsumsi makanan yang berlebih diperkirakan yang menyebabkan obesitas. ${ }^{3}$ Persentase kegemukan pada anak umur 6-11 tahun di Amerika sekitar 15\%. Data statistik 6 tahun terakhir di Arkansas, Amerika Serikat mencengangkan, yaitu persentase obesitas pada anak-anak di Arkansas sebesar 21\% dan kegemukan sebesar 17\%. Insiden dan prevalensi anak kegemukan dan obesitas di Amerika merupakan masalah kesehatan yang serius karena komplikasi dari obesitas dapat memiliki efek jangka panjang yang serius dan penyakit kardiovaskuler, sleep apnea, diabetes tipe 2, penyakit syaraf, dan penyakit paru (WHO., 2010). Persentase kegemukan dan obesitas pada anak sekolah (6-15 tahun) di Indonesia pada tahun 2010 sebesar 18,3\%. Data ini bila dibandingkan pada negara Arab Saudi dan Amerika Serikat relatif masih lebih rendah, dan bila dibandingkan dengan tujuh negara di Eropa hampir sama (Phillips 2013; Barkley 2012).

Namun kita tidak boleh lengah karena persentase kegemukan dan obesitas di Indonesia lebih tinggi dibandingkan persentase kurus yang sebesar 12,3\%. Tidak hanya itu, berdasarkan Riset Kesehatan Dasar (Riskesdas) dari tahun 2007 sampai dengan tahun 2013 persentase kegemukan pada anak 
sekolah semakin meningkat. Riskesdas tahun 2007 menunjukkan persentase kegemukan pada usia 6-14 tahun anak laki-laki sebesar 9,5\% dan anak perempuan sebesar $6,4 \%$. Riskesdas tahun 2010 menunjukkan persentase kegemukan pada anak 6-12 tahun sebesar 9,2\%. Riskesdas tahun 2013 menunjukkan peresentase kegemukan pada anak usia 5-12 tahun meningkat menjadi $10,8 \%$.

Obesitas pada anak-anak dapat menyebabkan beberapa penyakit kronis meliputi gangguan metabolime glukosa, resistensi insulin, diabetes tipe 2 pada remaja, hypertensi, dyslipidemia, steatosis hepatic, gangguan gastrointestinal, dan obstruksi pernafasan pada waktu tidur (Kemenkes RI., 2012).

Obesitas merupakan penyakit multifaktorial yang disebabkan oleh interaksi antara faktor internal dan eksternal. Sebagian besar obesitas disebabkan karena faktor eksternal sedangkan faktor internal hanya menyumbang sebesar 10\%. Faktor eksternal, aktivitas fisik memiliki hubungan yang bermakna terhadap obesitas dibanding dengan faktor eksternal lainnya. Hubungan anatara aktivitas fisik dan obesitas berkaitan dengan pengeluaran energi dimana lemak tubuh berhubungan dengan obesitas dipengaruhi secara langsung oleh asupan energi dan total pengeluaran energi. Aktivitas fisik memberi peran penting dalam pengeluaran energi karena 20-50\% energi dikeluarkan dengan aktivitas fisik. Kurang aktivitas fisik menyebabkan kelebihan energi akan disimpan dalam bentuk jaringan lemak (Gouw et al., 2010).

Obesitas anak diprediksi berhubungan dengan kebiasaan yang tidak aktif yang mengarah pada perilaku kurang gerak (sedentary behavior). Sedentary behavior menimbulkan efek negatif terhadap kesehatan, saat ini sedentary behavior menjadi isu penting dalam kesehatan masyarakat. Sedentary behavior merupakan sekelompok perilaku yang terjadi saat duduk atau berbaring yang membutuhkan pengeluaran energi yang sangat rendah, seperti duduk atau berbaring sambil menonton televisi, bermain game elektronik, membaca, dan lain sebagainya. Kemajuan berbagai bentuk kemudahan (instant) menyebabkan penurunan aktivitas fisik yang menjurus pada peningkatan sedentary behavior pada anak yang menghasilkan pola hidup santai yang berakibat terhadap obesitas (Arundhana et al., 2013).

Sedentary behavior mengakibatkan energi yang tadinya untuk aktivitas tidak terlalu diperlukan yang kemudian disimpan sebagai timbunan lemak dan akhirnya menimbulkan obesitas. Berbagai penelitian mengungkapan terdapat hubungan bermakna antara sedentary behavior dengan obesitas.

Sebagian besar anak-anak saat ini menghabiskan waktunya melakukan aktivitas yang menjurus pada sedentary behavior seperti menonton tv, bermain game, dan bermain gadget. Salah satu penyebab kegemukan anak adalah gaya hidup kurang gerak yaitu kurang aktivitas fisik, seperti menonton tv dan bermain handphone (screen based activity) lebih dari 2 jam/hari. Semakin lama waktu menonton tv dihubungkan dengan risiko komposisi tubuh yang tidak sehat dan peningkatan IMT. Selain itu, tv di kamar tidur 
dihubungkan dengan waktu penggunaan screen based activity (SBA) lebih banyak. Anak yang memiliki tv dalam kamar tidur lebih cenderung menjadi overweight. Selain itu, anak yang menonton tv 3 jam/hari cenderung $48 \%$ menjadi lebih obesitas dibanding anak yang menonton tv $<1 \mathrm{jam} / \mathrm{hari}$.

Screen based activity(SBA) terutama tv dihubungkan dengan rendahnya konsumsi sayur dan buah serta tingginya konsumsi camilan tinggi kalori, makanan cepat saji, dan minuman kemasan tinggi gula. Iklan makanan dan minuman yang ditayangkan selama anak menonton tv berkontribusi pada kegemukan anak. Peningkatan asupan energi saat SBA karena ketidaktepatan pilihan makanan yaitu konsumsi makanan ringan dengan densitas energi tinggi (makanan tinggi tambahan gula dan lemak) dan kurangnya kontrol pada jumlah pori yang dimakan (Yu et al., 2010).

Anak yang menonton tv atau menggunakan komputer 4 jam dalam sehari mempunyai peluang 2,5 kali lebih besar menjadi obesitas daripada anak yang menonton tv atau menggunakan komputer selama 1 jam. Penelitian lain menyebutkan bahwa anak dengan obesitas menghabiskan 2-3 jam lebih banyak waktu untuk melakukan aktivitas dengan energi rendah seperti menggunakan komputer, bermain game, belajar, dan menggunakan transportasi pasif (motor, bus, mobil) ke sekolah dibandingkan dengan anak berat badan normal.

Obesitas pada anak memerlukan tatalaksana yang baik. Obesitas menimbulkan dampak negatif terhadap psikososial yang berakibat pada rasa rendah diri, depresi dan menarik diri dari lingkungan. Anak obesitas memiliki kecenderungan untuk berlanjut hingga dewasa sehingga berpotensi memicu terjadinya penyakit metabolik dan penyakit degeneratif seperti hipertensi, stroke, infark myokard acute, gagal jantung, diabetes mellitus, obstruksi sleep apnea, gangguan pada tulang di kemudian hari. Penyakit yang ditimbulkan pada akhirnya akan menyebabkan penurunan kualitas hidup(Mushtaq et al., 2011).

\section{Metode}

Metode yang digunakan yaitu metode studi tinjauan literature (literature review) yang mencoba menggali bagaimana pengaruh sedentary behavior terhadap obesitas pada anak sekolah. Sumber untuk melakukan tinjauan literatur ini meliputi studi pencarian sistematis database terkomputerisasi (Pubmed, Google Scholar) yang dibatasi pada tahun pencarian pada tahun 2013-2018 pada pubmed dan Googlw Scolar 2020-2021 dalam bentuk jurnal penelitian berjumlah 21 jurnal. Dengan kata kunci Sedentary behavior, Obesity, School children. Kriteria inklusif dan eksekusi review artikel dalam penelitian ini:

\begin{tabular}{llll}
\hline \multicolumn{1}{c}{ Kriteria Inklusi } & \multicolumn{1}{c}{ Kriteria Ekslusi } \\
\hline 1 & $\begin{array}{l}\text { Original article, Original research dan Meta } \\
\text { Analysis }\end{array}$ & Artikel Opini \\
& $\begin{array}{l}\text { Artikel diterbitkan dalam data base Pubmed, } \\
\text { Google Scholar }\end{array}$ & $\begin{array}{l}\text { Dokumentasi laporan/draf kebijakan/pedoman } \\
\text { dari WHO /organisasi tertentu }\end{array}$ \\
3 & $\begin{array}{l}\text { Artikel yang membahas tentang sedentary } \\
\text { behavior terhadap obesitas pada anak sekolah }\end{array}$ & \\
\hline
\end{tabular}




\section{Hasil dan Pembahasan}
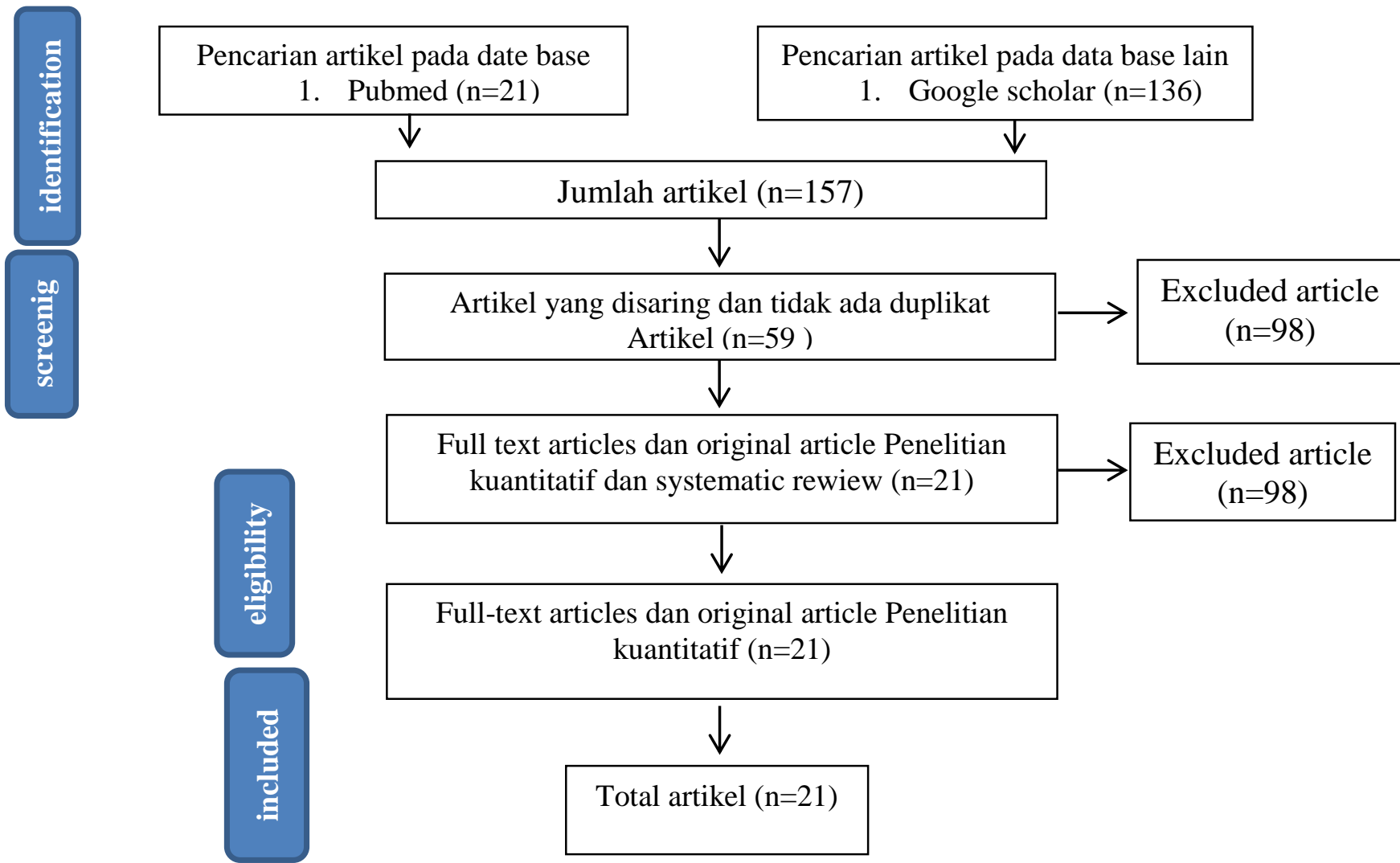

\begin{tabular}{|c|c|c|c|c|c|}
\hline Peneliti & Judul & Sampel & Metode & Hasil penelitian & $\begin{array}{c}\text { Kelebihan dan } \\
\text { keterbatasan }\end{array}$ \\
\hline $\begin{array}{c}\text { Sartika, R.A.D, } \\
2011\end{array}$ & $\begin{array}{l}\text { Risk Factors for } \\
\text { Obesity in Children 5- } \\
15 \text { Years in Indonesia }\end{array}$ & 170.699 & $\begin{array}{c}\text { Cross } \\
\text { sectional }\end{array}$ & $\begin{array}{l}\text { Perlunya menanamkan } \\
\text { pendidikan kesehatan } \\
\text { pada anak sejak usia } \\
\text { dini, melalui peningkatan } \\
\text { komunikasi, informasi } \\
\text { dan edukasi (KIE), } \\
\text { seperti gerakan anti } \\
\text { rokok, gerakan cinta } \\
\text { serat (sayur dan buah), } \\
\text { budayakan aktivitas fisik } \\
\text { dan lain-lain. }\end{array}$ & $\begin{array}{l}\text { Kelebihan pada } \\
\text { penelitian ini } \\
\text { adalah metode } \\
\text { yang digunakan }\end{array}$ \\
\hline $\begin{array}{l}\text { Al Qahtani, } \\
\text { et.al, } 2013\end{array}$ & $\begin{array}{l}\text { Childhood Obesity } \\
\text { Prevalence, risk factors } \\
\text { and lifestyle behavior } \\
\text { among primary school } \\
\text { male children in Al- } \\
\text { Madinah Al- } \\
\text { Munawarah, Saudi } \\
\text { Arabia }\end{array}$ & 1.023 & $\begin{array}{c}\text { Cross } \\
\text { sectional }\end{array}$ & $\begin{array}{l}\text { Menunjukkan tren pada } \\
\text { orang tua dari anak-anak } \\
\text { obesitas, mengadopsi } \\
\text { praktik diet yang tidak } \\
\text { sehat untuk anak-anak } \\
\text { mereka (lebih memilih } \\
\text { restoran cepat saji untuk } \\
\text { biaya mereka, } \\
\text { selera, dan kebijakan } \\
\text { ramah anak), tanpa } \\
\text { mengakui potensi } \\
\text { dampak negatif pada } \\
\text { mereka } \\
\text { kesehatan anak. }\end{array}$ & $\begin{array}{l}\text { Kelebihan pada } \\
\text { penelitian ini } \\
\text { adalah metode } \\
\text { yang digunakan }\end{array}$ \\
\hline
\end{tabular}




\begin{tabular}{|c|c|c|c|c|c|}
\hline $\begin{array}{c}\text { Beatriz O, et al, } \\
2015\end{array}$ & $\begin{array}{l}\text { Country-level and } \\
\text { individual correlates of } \\
\text { overweight and obesity } \\
\text { among primary school } \\
\text { children;a cross- } \\
\text { sectional study in } \\
\text { seven. European } \\
\text { countries }\end{array}$ & 5.206 & $\begin{array}{c}\text { Cross } \\
\text { sectional }\end{array}$ & $\begin{array}{l}\text { Tingkat prevalensi } \\
\text { kelebihan berat badan } \\
\text { dan obesitas pada anak } \\
\text { sekolah masih tinggi, } \\
\text { dengan beberapa faktor } \\
\text { sosio-demografis dan } \\
\text { gaya hidup yang terkait } \\
\text { dengan kelebihan berat } \\
\text { badan. }\end{array}$ & $\begin{array}{l}\text { Kelebihan pada } \\
\text { penelitian ini } \\
\text { adalah metode } \\
\text { yang digunakan }\end{array}$ \\
\hline $\begin{array}{c}\text { Duncan,S, et al, } \\
2011\end{array}$ & $\begin{array}{l}\text { Modifiable Risk } \\
\text { Factors for Overweight } \\
\text { and Obesity in Children } \\
\text { and Adolescents from } \\
\text { Sao Paulo, Brazil }\end{array}$ & 3.397 & Eksperimen & $\begin{array}{l}\text { kelebihan berat badan } \\
\text { dikaitkan dengan } \\
\text { transportasi yang kurang } \\
\text { aktif ke sekolah, makan } \\
\text { sebelum tidur, dan } \\
\text { konsumsi sarapan, } \\
\text { minuman ringan penuh } \\
\text { gula, gorengan, dan gula- } \\
\text { gula. }\end{array}$ & $\begin{array}{l}\text { Kelebihan pada } \\
\text { penelitian ini } \\
\text { adalah metode } \\
\text { yang digunakan }\end{array}$ \\
\hline $\begin{array}{c}\text { Barkley, et al, } \\
2012\end{array}$ & $\begin{array}{c}\text { An educational } \\
\text { intervention to increase } \\
\text { fruit and vegetable } \\
\text { consumption in parents } \\
\text { of obese and } \\
\text { overweight children. }\end{array}$ & 30 & $\begin{array}{c}\text { Cross } \\
\text { sectional }\end{array}$ & $\begin{array}{l}\text { Konsumsi buah-buahan } \\
\text { dan sayuran pada anak- } \\
\text { anak dikaitkan dengan } \\
\text { risiko yang lebih rendah } \\
\text { untuk } \\
\text { kelebihan berat badan } \\
\text { atau obesitas }\end{array}$ & $\begin{array}{l}\text { Kelebihan pada } \\
\text { penelitian ini } \\
\text { adalah metode } \\
\text { yang digunakan }\end{array}$ \\
\hline $\begin{array}{c}\text { Gouw,D, et.al, } \\
2010\end{array}$ & $\begin{array}{l}\text { Associations Between } \\
\text { Diet and (in) Activity } \\
\text { Behaviors with } \\
\text { Overweight and } \\
\text { Obesity Among 10-18 } \\
\text { years old Czech } \\
\text { Republic adolescents }\end{array}$ & 31.226 & $\begin{array}{c}\text { Cross } \\
\text { sectional }\end{array}$ & $\begin{array}{l}\text { Menonton TV lebih dari } \\
7 \text { jam seminggu secara } \\
\text { positif berhubungan } \\
\text { dengan kelebihan berat } \\
\text { badan/obesitas pada anak } \\
\text { perempuan berusia } 15-18 \\
\text { tahun, dan ditemukan } \\
\text { berhubungan negatif } \\
\text { pada anak laki-laki dari } \\
\text { kelompok usia yang } \\
\text { sama. }\end{array}$ & $\begin{array}{l}\text { Kelebihan pada } \\
\text { penelitian ini } \\
\text { adalah metode } \\
\text { yang digunakan }\end{array}$ \\
\hline $\begin{array}{c}\text { Yu,Zhangbin, } \\
\text { et al, } 2010\end{array}$ & $\begin{array}{l}\text { Trends in Overweight } \\
\text { and Obesity among } \\
\text { Children and } \\
\text { Adolescents in China } \\
\text { from } 1981 \text { to } 2010\end{array}$ & 35 & $\begin{array}{c}\text { Meta } \\
\text { Analysis }\end{array}$ & $\begin{array}{l}\text { Strategi pencegahan } \\
\text { kesehatan masyarakat } \\
\text { sangat dibutuhkan untuk } \\
\text { mengubah perilaku } \\
\text { kesehatan anak-anak dan } \\
\text { remaja dan } \\
\text { mengendalikan } \\
\text { kelebihan berat } \\
\text { badan/obesitas di Cina. }\end{array}$ & $\begin{array}{l}\text { Kelebihan pada } \\
\text { penelitian ini } \\
\text { adalah metode } \\
\text { yang digunakan }\end{array}$ \\
\hline $\begin{array}{c}\text { Mushtaq,MU, } \\
\text { et al, } 2011\end{array}$ & $\begin{array}{l}\text { Dietary Behaviors, } \\
\text { Physical Activity, and } \\
\text { Sedentary Lifestyle } \\
\text { Associated with } \\
\text { Overweight and } \\
\text { Obesity, and Their } \\
\text { Socio-Demographic } \\
\text { Correlates, Among } \\
\text { Pakistani Primary } \\
\text { School Children }\end{array}$ & 1860 & Eksperimen & $\begin{array}{l}\text { Perilaku diet, aktivitas } \\
\text { fisik dan gaya hidup } \\
\text { menetap adalah prediktor } \\
\text { independen dari } \\
\text { kelebihan berat badan } \\
\text { dan BMI yang lebih } \\
\text { tinggi di antara anak- } \\
\text { anak sekolah dasar } \\
\text { Pakistan, dan secara } \\
\text { signifikan dipengaruhi } \\
\text { oleh karakteristik sosio- } \\
\text { demografis anak. }\end{array}$ & $\begin{array}{l}\text { Kelebihan pada } \\
\text { penelitian ini } \\
\text { adalah metode } \\
\text { yang digunakan }\end{array}$ \\
\hline $\begin{array}{l}\text { Sisson SB, } \\
\text { et.al,2012 }\end{array}$ & $\begin{array}{c}\text { Television viewing } \\
\text { time and dietary quality } \\
\text { among U.S. Children } \\
\text { and Adults. }\end{array}$ & 14.737 & Eksperimen & $\begin{array}{l}\text { Lebih sedikit waktu yang } \\
\text { dihabiskan untuk } \\
\text { menonton TV dikaitkan } \\
\text { dengan kualitas makanan }\end{array}$ & $\begin{array}{l}\text { Kelebihan pada } \\
\text { penelitian ini } \\
\text { adalah metode } \\
\text { yang digunakan }\end{array}$ \\
\hline
\end{tabular}




\author{
Tremblay,M.S, Canadian Sedentary \\ et.al, 2011 behavior Guidelines for \\ Children and Youth
}

Pangesti, dkk, 2016

\begin{tabular}{|c|c|}
\hline $\begin{array}{l}\text { Iastoety,dkk, } \\
2017\end{array}$ & $\begin{array}{l}\text { Prevention of obesity in } \\
\text { school children }\end{array}$ \\
\hline $\begin{array}{l}\text { Dupuy M, } \\
\text { et.al,2011 }\end{array}$ & $\begin{array}{c}\text { Socio-demographic and } \\
\text { lifestyle factors } \\
\text { associated with } \\
\text { overweight in a } \\
\text { representative sample } \\
\text { of 11-15 year olds in } \\
\text { France: results from the } \\
\text { WHO-Collaborative } \\
\text { Health Behaviour in } \\
\text { School-aged Children } \\
\text { (HBSC) }\end{array}$ \\
\hline
\end{tabular}

Leandro, et.al. Sedentary Behavior and 2014

Wu, et.al, 2017

Screen Based Activity as a risk factor for obesity in pre-school children in the city of Yogyakarta

The Relationship between the Use of Setyoadi,dkk,2 Sedentary Behavior and 015 Obesity in Children aged 9-11 years at SDN 02 Tulungagung Regency.

The Influence of Physical Activity, Sedentary Behavior on Health-related Quality
Systematic review

34 orang

7 artikel

eligible

yang

masuk metaanalis

is

11-15

year-olds $(\mathrm{n}=7154)$

27 studi

Systematic review of life Among the General Population of Children and Adolescents

31 studi

Systematic yang lebih baik pada anak-anak dan orang dewasa AS.

Rekomendasi pedoman terakhir menyatakan bahwa untuk manfaat kesehatan, anak-anak (usia 5-11 tahun) dan remaja (usia 12-17 tahun) harus meminimalkan waktu yang mereka habiskan untuk tidak bergerak setiap hari.

Durasi SBA anak pada hari kerja dapat meningkatkan risiko terjadinya obesitas pada anak prasekolah di Yogyakarta anak obesitas lebih sering melakukan sedentary Eksperimen behaviour dibandingkan dengan anak berat badan normal

aktivitas fisik dan perilaku makan yang sehat secara bermakna dapat mencegah terjadinya obesitas

Perubahan gaya hidup di antara anak dengan kelas sosial ekonomi yang lebih tinggi termasuk penurunan aktivitas fisik dan meningkatnya hidup sedentary

Kelebihan pada penelitian ini adalah metode yang digunakan

kami menemukan pada anak-anak dan remaja, bukti kuat dari hubungan antara waktu yang dihabiskan dalam perilaku sedentary dan obesitas.

penelitian ini adalah metode yang digunakan

Kelebihan pada penelitian ini adalah metode yang digunakan

Temuan dalam penelitian ini menunjukkan bahwa program kesehatan sekolah yang mempromosikan gaya hidup aktif di kalangan anak-anak dan remaja dapat berkontribusi pada peningkatan kualitas hidup terkait kesehatan.
Kelebihan pada penelitian ini adalah metode yang digunakan
Kelebihan pada penelitian ini adalah metode yang digunakan 


\begin{tabular}{|c|c|c|c|c|c|}
\hline $\begin{array}{c}\text { Yang, et.al } \\
2017\end{array}$ & $\begin{array}{l}\text { Sedentary behavior and } \\
\text { Sleep Problems }\end{array}$ & 16 studi & $\begin{array}{l}\text { Systematic } \\
\text { review and } \\
\text { Meta } \\
\text { Analysis }\end{array}$ & $\begin{array}{l}\text { Perilaku sedentary yang } \\
\text { lama cenderung } \\
\text { dikaitkan dengan } \\
\text { peningkatan risiko } \\
\text { insomnia dan gangguan } \\
\text { tidur dalam literatur yang } \\
\text { ada }\end{array}$ & $\begin{array}{l}\text { Kelebihan pada } \\
\text { penelitian ini } \\
\text { adalah metode } \\
\text { yang digunakan }\end{array}$ \\
\hline $\begin{array}{l}\text { Barbosa,et. } \\
\text { al.2016 }\end{array}$ & $\begin{array}{l}\text { School environment, } \\
\text { sedentary behavior and } \\
\text { physical activity in } \\
\text { preschool children. }\end{array}$ & 370 & Eksperimen & $\begin{array}{l}\text { Infrastruktur sekolah dan } \\
\text { lingkungan harus dilihat } \\
\text { sebagai strategi untuk } \\
\text { mempromosikan } \\
\text { aktivitas fisik dan } \\
\text { mengurangi perilaku } \\
\text { malas bergerak pada } \\
\text { anak-anak prasekolah. }\end{array}$ & $\begin{array}{l}\text { Kelebihan pada } \\
\text { penelitian ini } \\
\text { adalah metode } \\
\text { yang digunakan }\end{array}$ \\
\hline $\begin{array}{l}\text { Carter, et.al, } \\
2016\end{array}$ & $\begin{array}{l}\text { Association Between } \\
\text { Portable Screen-Based } \\
\text { Media Device Acces or } \\
\text { Use and Sleep } \\
\text { outcomes. }\end{array}$ & 20 & $\begin{array}{l}\text { Systematic } \\
\text { review and } \\
\text { Meta } \\
\text { Analysis }\end{array}$ & $\begin{array}{l}\text { Anak-anak yang } \\
\text { memiliki akses ke } \\
\text { perangkat media di } \\
\text { malam hari lebih } \\
\text { cenderung memiliki } \\
\text { kuantitas tidur yang tidak } \\
\text { memadai, kualitas tidur } \\
\text { yang buruk dan kantuk di } \\
\text { siang hari yang } \\
\text { berlebihan. }\end{array}$ & $\begin{array}{l}\text { Kelebihan pada } \\
\text { penelitian ini } \\
\text { adalah metode } \\
\text { yang digunakan }\end{array}$ \\
\hline $\begin{array}{l}\text { Guerra, et.al, } \\
2016\end{array}$ & $\begin{array}{l}\text { Sedentary Behavior in } \\
\text { Brazilian Children and } \\
\text { Adolescents }\end{array}$ & 49 & $\begin{array}{l}\text { Systematic } \\
\text { review }\end{array}$ & $\begin{array}{l}\text { Variabel yang paling } \\
\text { sering dikaitkan dengan } \\
\text { perilaku menetap adalah } \\
\text { berat badan tingkat } \\
\text { berlebih dan tingkat } \\
\text { aktivitas fisik yang lebih } \\
\text { rendah. }\end{array}$ & $\begin{array}{l}\text { Kelebihan pada } \\
\text { penelitian ini } \\
\text { adalah metode } \\
\text { yang digunakan }\end{array}$ \\
\hline $\begin{array}{l}\text { Biddle, et.al, } \\
2017\end{array}$ & $\begin{array}{l}\text { Sedentary Behavior and } \\
\text { Adiposity in Youth: a } \\
\text { Systematic review of } \\
\text { Reviews and Analysis } \\
\text { of Causality }\end{array}$ & 29 & $\begin{array}{l}\text { Systematic } \\
\text { review }\end{array}$ & $\begin{array}{l}\text { Menghitung efek dari } \\
\text { pengurangan perilaku } \\
\text { menetap saja sulit karena } \\
\text { banyak intervensi } \\
\text { termasuk perubahan } \\
\text { tambahan dalam } \\
\text { perilaku, seperti aktivitas } \\
\text { fisik dan asupan } \\
\text { makanan. }\end{array}$ & $\begin{array}{l}\text { Kelebihan pada } \\
\text { penelitian ini } \\
\text { adalah metode } \\
\text { yang digunakan }\end{array}$ \\
\hline
\end{tabular}

Gizi sangat berpengaruh terhadap tumbuh kembang anak. Gizi diperlukan untuk memperbanyak dan memperbesar semua selsel terutama sel otak. Kekurangan gizi pada anak dapat menimbulkan beberapa efek negatif seperti lambatnya pertumbuhan bada, rawan terhadap penyakit, menurunnya tingkat kecerdasan (IQ), dan terganggunya pertumbuhan dan perkembangan anak. Sebaliknya makanan yang berlebihan juga tidak baik, karena dapat menyebabkan obesitas yang mengganggu tumbuh kembang anak.

Pemantauan perkembangan anak berguna untuk menemukan penyimpangan /hambatan perkembangan anak sejak dini, sehingga upaya pencegahan, upaya stimulasi dan upaya penyembuhan dapat diberikan dengan indikasi yang jelas dan sedini mungkin pada masa-masa tumbuh kembang.

Faktor yang berperan dalam terjadinya 
obesitas yang sebagian besar merupakan interaksi antara faktor genetik dengan faktor lingkungan, antara lain aktivitas fisik, sosial ekonomi, dan nutrisi. Perubahan gaya hidup menyebabkan terjadinya perubahan pengetahuan, sikap, perilaku, pola makan serta jumlah makanan yang dikonsumsi. Selain itu perubahan gaya hidup juga menurunkan frekuensi dan intensitas aktivitas fisik yang dilakukan. Penurunan aktivitas ini dapat dilihat dari penurunan intensitas olahraga dan permainan yang mempergunakan fisik pada anak digantikan jenis permainan elektronik (Sisson et., 2012).

Kegemukan dan obesitas terutama disebabkan oleh faktor lingkungan. Faktor genetik meskipun diduga juga berperan, tetapi tidak dapat menjelaskan terjadinya peningkatan prevalensi kegemukan dan obesitas. Pengaruh faktor lingkungan terutama terjadi melalui ketidakseimbangan antara pola makan, perilaku makan, dan aktivitas fisik (Octari et al., 2014).

Selain pola makan dan perilaku makan, kurangnya aktivitas fisik juga merupakan faktor penyebab terjadinya kegemukan dan obesitas pada anak sekolah. Keterbatasan lapangan untuk bermain dan kurangnya fasilitas untuk beraktivitas fisik menyebabkan anak tidak memilih untuk bermain (Barkley et al., 2012).

Obesitas adalah hasil dari asupan energi dari makanan lebih banyak daripada energi yang dibutuhkan tubuh untuk berbagai aktivitas. Diperkirakan kelebihan asupan energi berasal dari pilihan makanan yang dikonsumsi tidak sehat, misalnya mengomsumsi makanan dan minuman yang tinggi energi, lemak, dan gula (Tremblay et al., 2011).

Penelitian yang dilakukan di Yogyakarta menunjukkan perbedaan lama waktu Screen Based Activity (SBA) anak dalam kelompok gemuk dan tidak gemuk. Hanya SBA anak saat hari sekolah yang bermakna. Saat hari sekolah, rerata waktu SBA anak kelompok gemuk lebih lama 48 menit. Berdasarkan uji Spearman, SBA anak saat hari libur berhubungan dengan SBA saat hari sekolah dengan besarnya korelasi sedang. Semakin lama waktu SBA anak saat hari libur, maka semakin lama pula SBA saat hari sekolah. ( $\mathrm{p}=0,0005)$ (Neni et al., 2016).

Hasil penelitian di Tulungagung pada tahun 2015 menunjukkan bahwa terdapat hubungan yang menunjukkan bahwa hasil uji korelasi Spearman nilai significancy 0,000 yang menunjukkan bahwa korelasi antara penggunaan waktu sedentary behavior dengan obesitas pada anak usia 9-11 tahun adalah bermakna. Nilai korelasi Spearman sebesar 0,589 menunjukkan bahwa arah korelasi positif dengan kekuatan korelasi sedang. Dari hasil tersebut dapat disimpulkan bahwa anak obesitas lebih sering melakukan sedentary behavior dibandingkan dengan anak berat badan normal dengan nilai efektifitas 58,9\% sedangkan sisanya dipengaruhi faktor lain, mengingat bahwa obesitas disebabkan oleh multifactorial (Setyoadi et al., 2016).

Hasil meta analisis publikasi terbitan tahun 2010 sampai 2015 menunjukkan bahwa aktivitas fisik dan perilaku makan yang sehat secara bermakna dapat mencegah terjadinya 
obesitas sebesar 0,827 kali $\quad(\mathrm{p}=0,000)$ dibandingkan anak yang tidak melakukan aktivitas fisik dan perilaku makan yang sehat (Sri et al., 2015).

Perubahan gaya hidup di antara anak dengan kelas sosial ekonomi yang lebih tinggi termasuk penurunan aktivitas fisik dan meningkatnya hidup sedentary, diperkuat oleh banyak perubahan budaya yang terkait dengan globalisasi. Anak-anak pada keluarga sosial ekonomi tinggi diarahkan pada pola hidup tidak sehat, menggunakan mobil dan bus dari dan ke sekolah, aktivitas olahraga digantikan dengan menonton televisi, video game dan internet. Anak-anak dari keluarga yang memiliki kelas sosial ekonomi rendah tidak mampu mengikuti tren ini, dan cenderung aktif secara fisik (Dupuy et al., 2011).

Pendidikan orang tua sangat penting dalam tumbuh kembang anak karena dengan pendidikan yang baik, maka orang tua dapat menerima segala informasi dari luar terutama tentang cara pencegahan sedentary behavior yang berhubungan dengan obesitas pada anak.

Perubahan perilaku bagi anak sekolah dan remaja dalam penanganan dan pencegahan obesitas sangatlah penting. Hanya dalam program perubahan perilaku khususnya aktivitas fisik, sebaiknya diimbangi dengan memodifikasi lingkungan fisik dan sosial. Sebagai contoh di sekolah disediakan juga sarana dan prasarana untuk aktivitas fisik, misalnya sarana dan prasana tempat olahraga yang memadai.

\section{Kesimpulan}

Untuk mengatasi obesitas pada anak sekolah dengan melakukan intervensi peningkatan aktivitas fisik dan menjalani perilaku pola makan yang sehat dapat mengurangi prevalensi obesitas pada anak sekolah.

\section{Referensi}

Al Qahtani A, Riyadh AAG, Khalid AG. Childhood Obesity ; Prevalence, risk factors and lifestyle behavior among primary school male children in AlMadinah Al-Munawarah, Saudi Arabia. International Journal of Medical Science and Public Health Int J Med Sci Public Health. 2013;2 (4):1058-62.

Arundhana, AI., Thaha,R., dan Jafar,N. Aktivitas Fisik dan Asupan Kalsium sebagai Faktor Risiko Obesitas. Buletin Gizi Kita.2013.Yogyakarta.12(2):68-80.

Badan Penelitian dan Pengembangan Kesehatan. Riset Kesehatan Dasar 2013. Jakarta

Barkley, Zenesha R. An educational intervention to increase fruit and vegetable consumption in parents of obese and overweight children. Ann Arbor:University of North Florida;2012.

Beatriz O, Maria VM, Ondine P, Adina B, Mauro GC, Ceyda E, et al. Countrylevel and individual correlates of overweight and obesity among primary school children;a cross-sectional study in seven. European countries. BMC Public Health.2015;15:475.

Dupuy,M., Godeau,E., Vignes,C. and Ahluwalia,N. Socio-Demographic and Lifestyle Factors Associated with Overweight in a Representative Sample of 11-15 year olds in France:Results from the WHO-Collaborative Health Behavior in School-aged Children (HSBC) cross sectional study. Biomed Central Public Health.2011.11:442-447.

Gouw,D., Klepp,K.I., Vignerova,J., Lien,N., Steenhuis,I.H., and Wind,M. Associations Between Diet and (in) 
Activity Behaviors with Overweight and Obesity Among 10-18 years old Czech Republic adolescents. Public Health Nutr.13.2010. (10A):1701-7.

Kementerian Kesehatan RI. Pedoman pencegahan dan penanggulangan kegemukan dan obesitas pada anak sekolah. Jakarta : Kementerian Kesehatan RI;2012.

Mushtaq,MU., Gull,S., Mushtaq,K., Shahid,U., Shad,M.A., and Akram,J. Dietary Behaviors, Physical Activity, and Sedentary Lifestyle Associated with Overweight and Obesity, and Their Socio-Demographic Correlates, Among Pakistani Primary School Children. International Journal of Behavioral Nutrition and Physical Activity.2011.8:130 (1-13).

Neni Pangesti, I Made Alit Gunawan, Madarina Julia, Screen Based Activity sebagai factor risiko kegemukan pada anak pra sekolah di kota Yogyakarta. Jurnal Gizi Klinik Indonesia. Vol 13 No 1-Juli 2016 (34-41) SSN 1693-900X.

Octari,C., Liputo,N., Hubungan status ekonomi dan gaya hidup dengan kejadian obesitas pada siswa SDN 08 Alang Lawas Padang. Jurnal Kesehatan Andalas.2014:1.

Phillips MM, Raczynski JM, West DS, Pulley LV, Bursac Z, Leviton LC. The Evaluation of Arkansas Act 1220 of 2003 to reduce childhood obesity:conceptualization, design, and special challenges. Am J Community Psychol.2013;51:289-298.
Sartika, R.A.D. Faktor Risiko Obesitas Pada Anak5-15 Tahun di Indonesia. Journal UI.15:37.2011.

Setyoadi, Ika Setyo Rini, Triana Novitasari. Hubungan Penggunaan Waktu perilaku kurang gerak (Sedentary Behavior) dengan Obesitas pada Anak Usia 9-11 tahun di SDN 02 Kabupaten Tulungagung. Jurnal Ilmu Keperawatan. Vol:3.no.2.

Sisson SB, Shay CM, Broyles ST, Leyva M. Television viewing time and dietary quality among U.S. Children and Adults. AMEPRE.2012:43 (2):196-200.

Sri Poedji Hastoety Djaiman, Sihadi, Kencana Sari, Nunik Kusuma Wardani. Metaanalisis : Pencegahan obesitas pada Anak Sekolah.mpk.2015. v 27 il.4838.39-48.

Tremblay,M.S., Leblanc,A.G., Janssen,I., Kho,M.E., Hicks,A., Murumets,K., Colley,R.C., and Duggan,M., Canadian Sedentary behavior Guidelines for Children and Youth.Appl Physiol Nutr Metab.2011.36 (1):59-64.

World Health Organization. Global Recommendations on Physical Activity for Health.2010. Geneva:WHO Press.

Yu,Zhangbin, Shuping,H., Chun,Z., and Xirong,G. Trends in Overweight and Obesity among Children and Adolescents in China from 1981 to 2010: A Meta-Analysis.Am J Prev Med.2012.6:222-236 